\title{
The utility of red cell distribution width to predict mortality of septic patients in a tertiary hospital of Nepal
}

\author{
Rajan Ghimire* ${ }^{*}$, Yogendra Man Shakya, Tirtha Man Shrestha and Ram Prasad Neupane
}

\begin{abstract}
Background: Sepsis is a common problem encountered in the emergency room which needs to be intervened early. Predicting prognosis is always a difficult task in busy emergency rooms using present scores, which has several variables to calculate. Red cell distribution width (RDW) is an easy, cheap, and efficacious score to predict the severity and mortality of patients with sepsis.

Methods: This prospective analytical study was conducted in the emergency room of Tribhuvan University Teaching Hospital among the patients age $\geq 16$ years and with a clinical diagnosis of sepsis using qSOFA score. 148 patients were analyzed in the study by using a non-probability purposive sampling method.

Results: RDW has fair efficacy to predict the mortality in sepsis (Area under the Curve of $0.734 ; 95 \% \mathrm{C} . \mathrm{I}=0.649-$ $0.818 ;$-value $=0.000$ ) as APACHE II (AUC of $0.728 ; 95 \%$ C. I $=0.637$ to $0.819 ; p$-value $=0.000$ ) or SOFA (AUC of 0.680, $95 \%$ C. I = 0.591-0.770; $p$-value $=0.001$ ). Youden Index was maximum (37\%) at RDW value 14.75 , which has a sensitivity of $83 \%$ (positive likelihood ratio $=1.81$ ) and specificity of $54 \%$ (negative likelihood ratio $=0.32$ ). Out of 44 patients with septic shock 16 died (36.4\%) and among 104 patients without septic shock, 24 died (22.9\%) which had the odds ratio of 0.713 ( $p=0.555,95 \%$ C. $I=0.231-2.194)$. Overall mortality was $27.02 \%(n=40)$. RDW group analysis showed no mortality in RDW < 13.1 group, 3.6\% mortality in 13.1 to 14 RDW group, 22.0\% mortality in 14 to $>15.6$ RDW group and $45.9 \%$ mortality in $>15.6$ RDW group. Significant mortality difference was seen in 14 to $>$ 15.6 and $>15.6$ RDW subgroups with a $p$-value of 0.003 and 0.008 respectively.

Conclusion: Area under the curve value for RDW is fair enough to predict the mortality of patients with sepsis in the emergency room. It can be integrated with other severity scores (APACHE II or SOFA score) for better prediction of prognosis of septic patients.
\end{abstract}

Keywords: Red cell distribution width, Sepsis, Emergency care, Mortality

\section{Background}

Sepsis is defined as a life-threatening organ dysfunction caused by a dysregulated host response to infection. The incidence of sepsis varies among different studies with a wide range from 300 to 1000 cases/100,000 persons per

\footnotetext{
*Correspondence: biplawi.shashi@gmail.com

Department of General Practice and Emergency Medicine, Maharajgunj Medical Campus, Institute of Medicine, Tribhuvan University, Kathmandu, Nepal
}

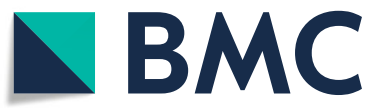

(c) The Author(s). 2020 Open Access This article is licensed under a Creative Commons Attribution 4.0 International License, which permits use, sharing, adaptation, distribution and reproduction in any medium or format, as long as you give appropriate credit to the original author(s) and the source, provide a link to the Creative Commons licence, and indicate if changes were made. The images or other third party material in this article are included in the article's Creative Commons licence, unless indicated otherwise in a credit line to the material. If material is not included in the article's Creative Commons licence and your intended use is not permitted by statutory regulation or exceeds the permitted use, you will need to obtain permission directly from the copyright holder. To view a copy of this licence, visit http://creativecommons.org/licenses/by/4.0/. The Creative Commons Public Domain Dedication waiver (http://creativecommons.org/publicdomain/zero/1.0/) applies to the data made available in this article, unless otherwise stated in a credit line to the data.
University Teaching Hospital, 10.49\% of patients showed bacterial growth in blood or bone marrow samples [2].

Organ dysfunction in the presence of infection increases in-hospital mortality by $10 \%$ [3]. One of the studies done in Nepal showed overall mortality from sepsis as $39.3 \%$ and a higher mortality rate among elderly patients (46.7\%) [4]. In a comparative metaanalysis, there was $33.2 \%$ mortality of severe sepsis 
patients during 28-days follow up [5]. Ongoing mortality in patients with sepsis remains elevated up to 2 years and beyond [6].

Nowadays, several indicators are being used to predict the prognosis of sepsis. Commonly used prognostic indicators include Acute Physiological and chronic health evaluation II (APACHE II), Sequential Organ Failure Assessment (SOFA), Mortality in Emergency Department Score (MEDS), New York Sepsis severity score. In recent years Red cell distribution Width (RDW) is being investigated for its prognostic value in septic patients.

Red cell distribution width (RDW) is an index of variation of erythrocyte volume (i.e. anisocytosis). It is conventionally included in a standard complete blood count $(\mathrm{CBC})$. The value of this parameter increases parallel with anisocytosis. It is conventionally increased in patients with anemia attributable to iron deficiency [7], folic acid/vitamin B12 deficiency, patients with autoimmune disorders [8], myelodysplastic syndrome, hemolytic anemia, liver impairment, sickle cell disease [9], and blood transfusions [10]. RDW value is increased among the red blood cell transfused patients [11] and a cutoff value of RDW to predict the mortality of critically ill patients was higher in comparison to non-transfused patients [12]. The normal range of RDW is 11.5 to $14.5 \%$ with no clinical scenarios that produce RDW < $11.5 \%$. Any process that results in the release of reticulocytes into the circulation will increase in RDW value.

When patients are infected, microbes release various toxins/lipopolysaccharides which activate inflammatory cascade via various interleukins, cytokines [13]. Cytokines are responsible for the clinically observable effects of the bacteremia in the host [14]. These cytokines induce direct red blood cell damage by erythrophagocytosis or apoptosis, interfere with iron homeostasis, inhibit erythropoiesis by myelosuppression and downregulate erythropoietin-receptor expression [13]. These mechanisms are thought to lead to anisocytosis and increased RDW value [15].

RDW has been utilized in diverse diseases other than traditionally for the interpretation of anemia. In chronic diseases, elevated RDW was associated with all-cause mortality in critically ill patients $[15,16]$ and increased mortality among healthy middle-aged [17] and older adults [18] from the general population and patients with cardiovascular disease [19], stroke [20], heart failure, and chronic dialysis [21]. In acute conditions, RDW can also be used as a mortality predictor among patients with acute pancreatitis [22], subarachnoid hemorrhage [23], acute dyspnea [24] during an emergency department visit [25], out-of-hospital cardiac arrest [26], cardiac arrest in ICU [27], and critical illnesses in an ICU setting. For septic patients, RDW was also found to be an independent indicator of mortality in patients with gram-negative bacteremia, community-acquired pneumonia, severe sepsis, and septic shock [28, 29]. For every $1 \%$ increase in RDW value, total mortality risk increased by $14 \%$ among older adults [18].

In the emergency condition like sepsis, a tool that can predict the severity and thus the prognosis of a patient is crucial in deciding the modality of treatment including the vasopressor, possible need of ventilator, empiric antibiotics or higher group of antibiotics. In the resourcelimited setting of developing countries like Nepal, calculating other prognostic indicators like APACHE II, MEDS, SOFA will be costly as well as time-consuming. RDW is a cost-effective and easy tool to predict the prognosis of critically ill patients including sepsis. Only a few studies of this type are conducted in developed nations and as developing nations have different health set up, this prospective analytical observational study is designed to find whether RDW can predict prognosis of septic patients in one of the tertiary centers of Nepal or not. If we can have a predicted prognosis of patients, we can decide the aggressiveness of treatment on time.

\section{Methods}

The primary aim of this study was to determine the utility of red cell distribution width (RDW) as a prognostic factor in septic patients. The secondary aim of the study was to compare the efficacy of RDW to predict the mortality of septic patients with APACHE II and SOFA scores.

\section{Study design}

This prospective observational study was conducted in Tribhuvan University Teaching Hospital (TUTH), Emergency Room, Maharajgunj, Kathmandu, Nepal from June 2017 to August 2018. Patients $\geq 16$ years with the clinical diagnosis of sepsis in the emergency room of TUTH were included in the study. Sepsis was suspected using qSOFA (quick Sequential Organ Failure Assessment) score. Patients with infection can be predicted to have sepsis if they have at least two of following clinical criteria that together constitute a new bedside clinical score termed as quickSOFA (qSOFA): respiratory rate of 22/ min or greater, altered mentation status or systolic blood pressure of $100 \mathrm{mmHg}$ or less [3, 30]. Septic shock can be clinically identified by a vasopressor requirement to maintain a mean arterial pressure of $65 \mathrm{mmHg}$ or greater and serum lactate greater than $2 \mathrm{mmol} / \mathrm{L}$ in the absence of hypovolemia [3]. The exclusion criteria were:

1. The patient who received blood transfusion within 90 days before emergency admission.

2. The patients who are known to have long-term conditions causing anemia like sickle cell anemia, thalassemia, iron deficiency anemia. 


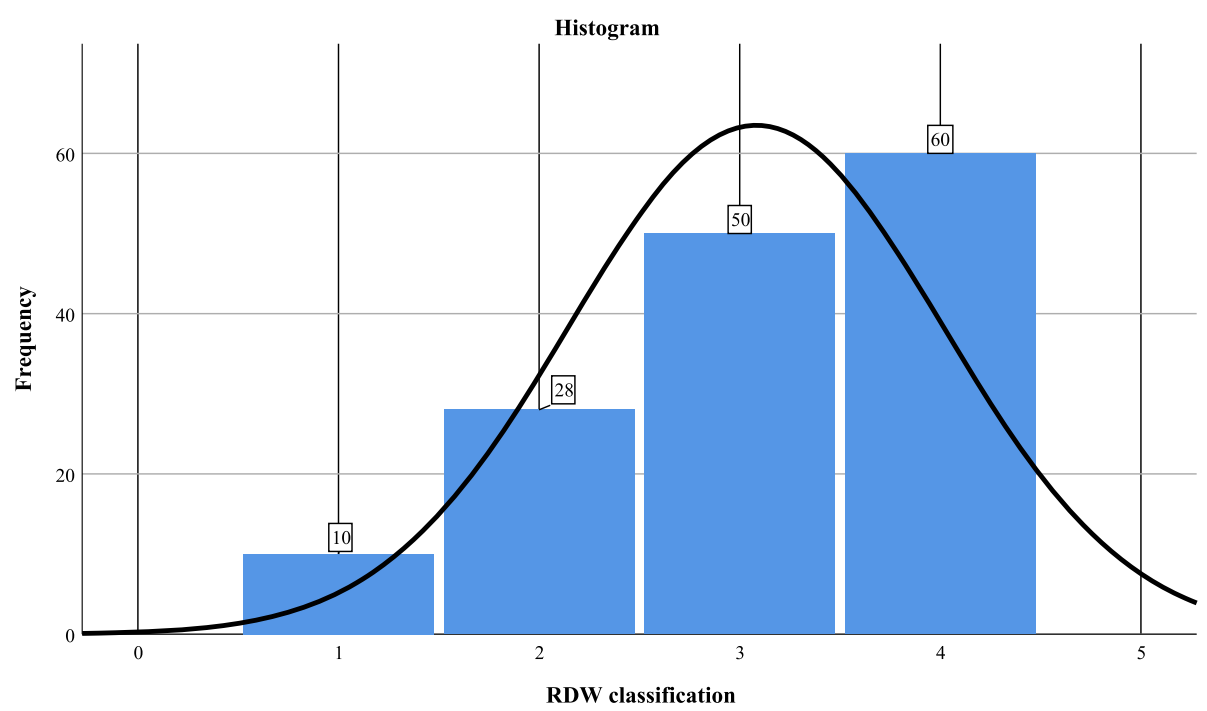

Fig. 1 Histogram of RDW classification; $1=$ RDW <13.1, $2=$ RDW $\geq 13.1-14,3=$ RDW $>14-15.6,4=$ RDW $\geq 15.6$

3. Patient with incomplete information and data.

4. The patient who deny consent.

\section{Sample size calculation}

Sample size was 144 which was calculated using Daniel method (sample size $=Z_{1-\alpha / 2}^{2} \mathrm{p}(1-\mathrm{p}) / \mathrm{d}^{2}$ ) [31]. For this purpose,' $Z_{1-\alpha / 2}$ is standard normal variate, 1.96 for $5 \%$ type I error; the expected proportion in populationbased previous studies (p) was $10.49 \%$ [2] and ' $\mathrm{d}$ ' is absolute error or precision ( 0.05 for $5 \%$ type I error).

\section{Data collection}

Patients with suspected infection and hence sepsis suggested by qSOFA score were enrolled into the study after getting formal written/oral consent from the patient or legal guardian available at the Emergency room. Only septic patients meeting the inclusion and exclusion criteria were enrolled in the study without any randomization of the samples. So, it was a nonprobability sampling method. Patient's basic demographic information, vital signs on ER arrival, symptoms and underlying diseases, provisional diagnosis and laboratory values required for analysis of RDW, APACHE II, and SOFA score were collected. Clinical outcome of patients was followed by phone calls made at 28-day

Table 1 Mann-Whitney $U$ test for predicting mortality among septic patients

\begin{tabular}{lll}
\hline Variable & Mann-Whitney U-Test & $p$-value \\
\hline Age & 2808.5 & 0.005 \\
RDW & 3422.0 & 0.000 \\
APACHE II & 3119.5 & 0.000 \\
SOFA & 2866.5 & 0.002 \\
\hline
\end{tabular}

from the day of ER admission. Patients who were in hospital till 28-days were followed in the respective admitted wards or critical care units. Collected data were then analyzed. Data collection was done by the researcher.

\section{Laboratory measurements}

RDW was a part of the automated complete blood count analysis. It was measured using the Nihon-Kohden automated hematology system analyzer. The normal laboratory range of RDW in our institution is 11.5 to $14.5 \%$.

\section{Statistical analysis}

Descriptive statistics of demographic and laboratory variables are calculated as mean, median, numbers, and percentages. Patients were further stratified a priori based on RDW values as: RDW < 13.1\%; RDW $\geq 13.1-14 \%$; RDW > 14-15.6\%; RDW $\geq 15.6 \%$ [25]. An odds ratio was used to compare differences in mortality between groups. Binary logistic regression was used to evaluate potential confounding between risk factors, RDW, and mortality. Receiver operating characteristics (ROC) curve analysis was done to evaluate the performance of RDW in predicting mortality within 28-days of ER admission. The area under the ROC curve was compared between different clinical prognosis score viz. RDW, APACHE II, and SOFA. All $p$ values $<0.05$ were considered statistically significant. Statistical analysis was performed using IBM SPSS (Statistical Package for Social Sciences) version 25.

\section{Results}

A total of 148 patients were analyzed. Mean age was 51.29 years $(S . D=20.22)$ with a mean age in survival 
Table 2 Binary logistic regression analysis of confounding factors and prognosis predictive scores

\begin{tabular}{|c|c|c|c|c|c|c|c|c|c|c|c|}
\hline & & \multicolumn{6}{|l|}{ Outcome } & \multirow[t]{3}{*}{$p$-value } & \multirow{3}{*}{$\begin{array}{l}\text { Odds } \\
\text { Ratio }\end{array}$} & \multirow{2}{*}{\multicolumn{2}{|c|}{$95 \%$ C.I }} \\
\hline & & \multicolumn{3}{|c|}{ Improved/Cured $(N=108)$} & \multicolumn{3}{|c|}{ Mortality $(N=40)$} & & & & \\
\hline & & Mean (S.D) & $\%$ & $n$ & Mean (S.D) & $\%$ & $n$ & & & Lower & Upper \\
\hline \multicolumn{2}{|l|}{ Age (years) } & $48.4(19.94)$ & $73.0 \%$ & 108 & $59.10(19.1)$ & $27.0 \%$ & 40 & 0.101 & 1.250 & 0.958 & 1.632 \\
\hline \multicolumn{2}{|l|}{ Hematocrit \% } & $35.3(8.8)$ & $73.0 \%$ & 108 & $33.6(10.1)$ & $73.0 \%$ & 40 & 0.315 & 0.979 & 0.941 & 1.020 \\
\hline \multicolumn{2}{|l|}{ SOFA } & $6(3)$ & $73.0 \%$ & 108 & $8(3)$ & $27.0 \%$ & 40 & 0.062 & 1.221 & 0.990 & 1.506 \\
\hline \multicolumn{2}{|l|}{ APACHE ॥ } & $16(7)$ & $73.0 \%$ & 108 & $21(7)$ & $27.0 \%$ & 40 & 0.157 & 1.053 & 0.983 & 1.131 \\
\hline \multicolumn{2}{|l|}{ RDW } & $15.2(2.2)$ & $73.0 \%$ & 108 & $17.9(2.9)$ & $27.0 \%$ & 40 & 0.000003 & 1.551 & 1.292 & 1.863 \\
\hline \multirow[t]{2}{*}{ Sex } & Male & - & $65.0 \%$ & 39 & - & $35.0 \%$ & 21 & 0.029 & 2.950 & 1.120 & 7.773 \\
\hline & Female & - & $78.4 \%$ & 69 & - & $21.6 \%$ & 19 & & & & \\
\hline \multirow[t]{2}{*}{ Septic shock } & Yes & - & $63.6 \%$ & 28 & - & $36.4 \%$ & 16 & 0.555 & 0.713 & 0.231 & 2.194 \\
\hline & No & - & $76.9 \%$ & 80 & - & $23.1 \%$ & 24 & & & & \\
\hline
\end{tabular}

group 48.4 years (S. $\mathrm{D}=19.94)$ and mortality group 59.10 years $(S . \quad D=19.1)$. The maximum number of people lied in age-group $60-70$ years $(n=28,18.9 \%)$ followed by 20-30 and $>70$ years both of which have the same numbers. Data is negatively skewed $(-0.217)$. In the study, there were more females $(88,59.5 \%)$ than males $(60,40.5 \%)$.

Most of the patients lie in group with RDW > 15.6 $(n=60,40.5 \%)$. (Figure 1). Mean RDW was 15.933 $(\mathrm{S} . \mathrm{D}=2.69)$. Data for RDW groups was negatively skewed (-0.678).

As data did not follow normal distribution (negatively skewed) nonparametric test (Mann-Whitney U test) was done to test the difference of distribution of Age, RDW, APACHE II and SOFA across the categories of clinical outcome (improved and mortality). The test showed a significant difference between the improved and mortality group with a $p$-value of $0.005,0.000,0.000,0.002$ for age, RDW, APACHE II, SOFA respectively (Table 1).

Binary logistic regression analysis was done to analyze the effect of confounding factors like age, sex, presence of septic shock on mortality. Results showed no significant effect of these confounding factors on mortality except for sex $(p=0.029$, Odds ratio $=2.950,95 \%$ C. $\mathrm{I}=1.120-7.773)$ (Table 2). Among the predictive scores viz. RDW, APACHE II, and SOFA scores; only RDW had a significant difference in predicting mortality with an odds ratio of 1.551 ( $p=0.000003,95 \%$ C. $\mathrm{I}=1.292-1.863)$. So RDW is a better prognostic test to predict mortality in septic patients.
Patients were further divided into two groups: (a) sepsis and (b) septic shock. Out of 44 patients with septic shock 16 died (36.4\%) and among 104 patients without septic shock, 24 died (23.1\%) with odds ratio of 0.713 $(p=0.555$, 95\% C.I $=0.231-2.194) \quad$ (Table 2). Overall mortality was $27.02 \%(n=40)$.

RDW group analysis showed no mortality in RDW < 13.1 group, $3.6 \%$ mortality in RDW $>13.1-14$ group, $22.0 \%$ mortality in RDW >14-15.6 group and $46.7 \%$ mortality in >15.6) RDW group (Table 3). Significant mortality difference was seen in >14-15.6 and $>15.6$ RDW groups with $p$-value 0.003 and 0.008 respectively. This shows an increasing trend of mortality with the increase in RDW value and vice-versa.

Receiver Operating Characteristic (ROC) curve was used to test the efficacy of different clinical scores viz. RDW, SOFA, APACHE II to predict mortality in septic patients (Fig. 2). Area under the ROC curve was analyzed which shows RDW, APACHE II and SOFA were fair tests to predict mortality in sepsis with AUC of 0.734 (95\% C. I = 0.649-0.818; $p$-value $=0.000), 0.7 .28$ (95\% C. $\mathrm{I}=0.637$ to 0.819 ; p-value $=0.000)$, and 0.680 $(95 \%$ C. I $0.591-0.770 ; p$-value $=0.001)$ respectively (Table 4). AUC of RDW is $>0.7$ which is considered a fair test.

RDW value of 15.05 has a sensitivity of $73 \%$ (positive likelihood ratio $=1.82$ ) and specificity of $60 \%$ (negative likelihood ratio $=0.45$ ) while RDW value of 16.1 has sensitivity of $56 \%$ (positive likelihood ratio =

Table 3 Binary logistic regression of RDW group and outcome

\begin{tabular}{|c|c|c|c|c|c|c|c|c|}
\hline \multirow{2}{*}{$\begin{array}{l}\text { RDW } \\
\text { Classification }\end{array}$} & \multicolumn{2}{|c|}{ Improved/Cured $(N=108)$} & \multicolumn{2}{|c|}{ Mortality $(N=40)$} & \multirow{2}{*}{$\begin{array}{l}\text { Odds } \\
\text { Ratio }\end{array}$} & \multirow{2}{*}{$\begin{array}{l}p- \\
\text { Value }\end{array}$} & \multicolumn{2}{|c|}{$95 \%$ C.I } \\
\hline & $n$ & $\%$ & $n$ & $\%$ & & & Lower & Upper \\
\hline$<13.1$ & 10 & $9.3 \%$ & 0 & $0.0 \%$ & 0.000 & 0.003 & 0.000 & 0.000 \\
\hline$>13.1-14$ & 27 & $25.0 \%$ & 1 & $2.5 \%$ & 0.00 & 0.999 & 0 & 0 \\
\hline$>14-15.6$ & 39 & $36.1 \%$ & 11 & $27.5 \%$ & 0.042 & 0.003 & 0.005 & 0.332 \\
\hline$>15.6$ & 32 & $29.6 \%$ & 28 & $70.0 \%$ & 0.332 & 0.008 & 0.139 & 0.746 \\
\hline
\end{tabular}



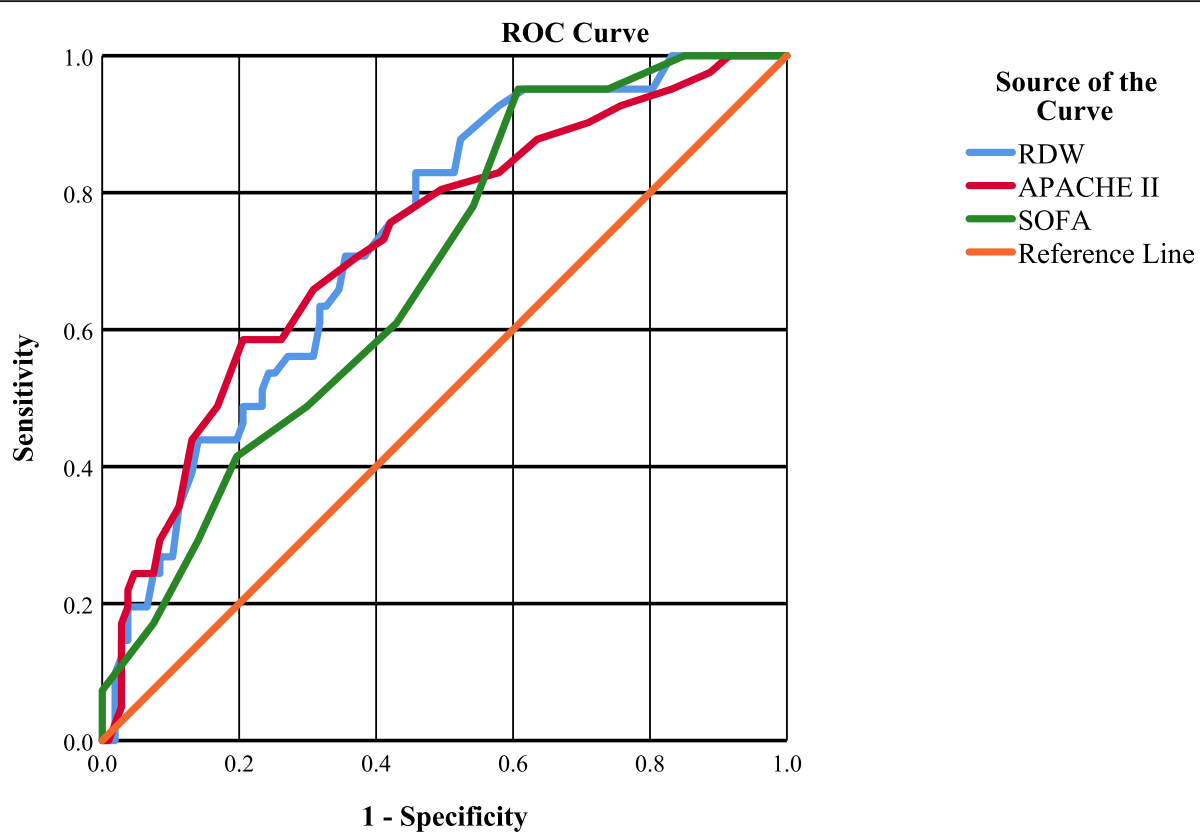

Fig. 2 Receiver operating characteristics curve analysis for RDW, SOFA, and APACHE II to predict mortality in sepsis

2.07 ) and specificity of $73 \%$ (negative likelihood ratio $=0.6)$. Youden Index was maximum $(37 \%)$ at RDW value 14.75 which has a sensitivity of $83 \%$ (positive likelihood ratio $=1.81$ ) and specificity of $54 \%$ (negative likelihood ratio $=0.32$ ). Increasing the value of RDW decreases the sensitivity of the test and increases the specificity of the test.

\section{Discussion}

This prospective analytical study illustrated the significant differences in RDW levels between mortality and survivor groups of septic patients. This study aimed to find the performance of RDW to predict the mortality of septic patients. The performance of RDW to predict mortality in septic patients was found at least equivalent to other clinical scores like SOFA, APACHE II.

Over 500,000 patients each year present to an emergency department with suspected severe sepsis [32]. Sepsis incidence increases $>100$ fold with the age $(0.2$ per 1000 in children age 10 to 14 years to 26.2 per 1000 in

Table 4 Area under the ROC curve for RDW, APACHE II, SOFA to predict mortality of sepsis

\begin{tabular}{lllll}
\hline Test & Area & Sig. & \multicolumn{2}{l}{$95 \%$ Confidence Interval } \\
\cline { 4 - 5 } Variable(s) & & & Lower Bound & Upper Bound \\
\hline SOFA & 0.680 & 0.001 & 0.591 & 0.770 \\
RDW & 0.734 & 0.000 & 0.649 & 0.818 \\
APACHE II & 0.728 & 0.000 & 0.637 & 0.819 \\
\hline
\end{tabular}

those $>85$ years of age) [33]. In our study, the overall mortality in septic patients was $27.02 \%(n=40)$ and the mortality in septic shock patients was $36.4 \%$ which is near to mortality rate shown by a meta-analysis of multicenter randomized- trials by Stevenson EK and et al. [5] This meta-analysis had $33.2 \%$ mortality from severe sepsis.

Our study showed higher mortality in the septic shock group than patients without septic shock $(36.4 \%$ vs $23.07 \%)$. In another study, among the severely septic patients $(n=2110), 13.8 \%$ died $(n=290)$, which is significantly higher compared with the non-severe septic group (3.8\%, $n=187, P<0.001)$ [25].

We found that mortality $(46.7 \%)$ was more in the RDW > 15.6 group. Mortality subsequently increased with an increase in RDW value. RDW had a significant ability to predict mortality in septic patients $(p=$ 0.000, Mann Whitney U Test). Kim J et al. showed that RDW was a particularly strong predictor of allcause mortality, 30 days following critical care initiation [26].

In our study, the area under the ROC curve of RDW showed a fair capacity of RDW to predict mortality in septic patients $(\mathrm{AUC}=0.734)$. AUC of RDW was greater than that of SOFA and APACHE II $(A U C=0.680$ and 0.728$)$. In another study, the area under the receiver operating characteristic curve of RDW to predict mortality was 0.75 (95\% confidence interval, 0.72-0.77), which is significantly higher than the areas under the curve of clinical prediction rules (SIRS, MEDS, and CURB65) [25]. AUC of RDW is > 
0.7 which is considered a fair test [34]. However, Fontana et al. showed no correlation between RDW and prognosis of septic patients [35].

Our study found that the sensitivity of RDW at 15.05 was $73 \%$ (Positive likelihood ratio $=1.82$ ) and specificity of $60 \%$ (Negative likelihood ratio $=0.45$ ). Decreasing the RDW value increases sensitivity while decreasing the specificity and vice versa. In a study by Chen et al.; using $12 \%$ as a cutoff of RDW, the sensitivity in predicting mortality would be $99.4 \%$ (negative likelihood ratio: 0.30 ). On the other hand, the specificity in predicting mortality would be $89.9 \%$ if $17 \%$ used as the cutoff of RDW (positive likelihood ratio: 3.16) [25].

There were certain limitations to our study. All the data and patients were collected in a single-center so the findings may not apply in the general population. As a purposive non-probability sampling method was used there is a chance of selection bias. The severity of the disease, patient characteristics, the value of RDW, and treatment protocol may vary with different institutes and hence the outcome of patients. Though the findings in patients with hematocrit $<36 \%$ are also applicable, patients with undiagnosed chronic anemia may have created biases and baseline hemoglobin of patients visiting the emergency room was lacking. Sepsis was diagnosed clinically using qSOFA which has low sensitivity due to which fewer cases might have been enrolled in the study.

RDW is a cheap and widely available test that has efficiency equivalent, if not more than the SOFA or APACHE II score. So it can be used in an emergency room or bedside or in a set-up where arterial blood gas analysis is not available to predict the severity/ mortality of septic patients. This study provides level III evidence for its use in day by day life. However, a multicenter study involving different geographical conditions and randomized sampling method will help to reduce biases involved in the study. Separate studies need to be done before using findings to patients with anemia of different causes.

\section{Conclusion}

RDW has fair enough efficacy to be used as a prognostic score to predict the mortality of patients with sepsis in the emergency room. RDW can be a part of the severity score along with APACHE II or SOFA score to predict mortality in septic patients. Further studies are required to confirm these data.

\section{Abbreviations}

APACHE II: Acute Physiological and Chronic Health Evaluation II; AUC: Area under the curve; ER: Emergency Room; qSOFA: Quick Sequential Organ Failure Assessment; RDW: Red cell distribution width; SOFA: Sequential Organ Failure Assessment

\section{Acknowledgments}

Not applicable.

\section{Authors' contributions}

As this study was conducted for partial fulfillment of the requirement of Doctor of Medicine in General Practice and Emergency Medicine, RG conducted the whole of the process of study. YMS helped to conceptualize and design the research. TMS analyzed the data and RPN interpreted the results. Besides YMS, TMS and RPN guided through the process as a guide and co-guides respectively. All the authors have read the manuscript and authorize it for publication.

\section{Funding}

This study was funded by authors.

\section{Availability of data and materials}

The datasets used and/or analyzed during the current study are available from the corresponding author on reasonable request.

\section{Ethics approval and consent to participate}

Ethical clearance was done from the Institutional Review Board of Institute of Medicine, Tribhuvan University. Written consent was taken from the patient. In conditions like mentally disabled, not able to give consent because of the critical medical condition, parent/legal guardian consented to participate in research and publish the findings.

\section{Consent for publication}

Not applicable.

\section{Competing interests}

The authors declare that they have no competing interests.

Received: 23 May 2019 Accepted: 14 May 2020

Published online: 26 May 2020

\section{References}

1. Gaieski DF, Edwards JM, Kallan MJ, Carr BG. Benchmarking the incidence and mortality of severe Sepsis in the United States. Crit Care Med. 2013;41: 1167-74. https://doi.org/10.1097/CCM.0b013e31827c09f8.

2. Chaudhary R, Karmacharya S, Shrestha S, Dahal RK, Mishra SK, Banjade NR, et al.. Incidence of Bacteremia and Septicemia in patients attending in tertiary care center, Nepal.J Inst Med. 2012. p. 32-38. Available from: www. jiom.com.np.

3. Singer M, Deutschman Clifford S. SCW, Manu SH, Djillali a, Michael B, Bellomo R, et al. The third international consensus definitions for Sepsis and septic shock (Sepsis-3). JAMA. 2016;315:801-10. https://doi.org/10.1001/jama. 2016.0287.

4. Lakhey S, Karki B, Shrestha B, Shakya S, Pandey SB. Sepsis_a private hospital experience in Nepal _ Lakhey _ journal of Institute of Medicine. J Inst Med. 2006;28.

5. Stevenson EK, Rubenstein AR, Radin GT, Wiener RS, Walkey AJ. Two decades of mortality trends among patients with severe Sepsis: a comparative metaanalysis Elizabeth. Crit Care Med. 2014;42:625-31. https://doi.org/10.1097/ CCM. 0000000000000026

6. Winters BD, Eberlein M, Leung J, Needham DM, Pronovost PJ SJ. Long-term mortality and quality of life in sepsis_a systematic review. Crit Care Med. 2010;38:1276-86. https://doi.org/10.1097/CCM.0b013e3181d8cc1d.

7. Bessman JD, Gilmer PR, Gardner FH. Improved Classification of Anemias by MCV and RDW. Am J Clin Pathol. Oxford Academic. 1983;80:322-6. Available from: https://academic.oup.com/ajcp/article/80/3/322/1803902. https://doi. org/10.1093/ajcp/80.3.322. [cited 202017 Feb].

8. Hu Z-D. Red blood cell distribution width: a promising index for estimating activity of autoimmune disease. J Lab Precis Med. AME Publishing Company; 2016;1. https://doi.org/10.21037/jlpm.2016.10.02.

9. Webster P, Castro O. Red cell distribution width in sickle cell disease. Ann Clin Lab Sci. Association of Clinical Scientists. 1986;16:274-7. Available from: http://www.ncbi.nlm.nih.gov/pubmed/3740796. [cited 202017 Feb].

10. Lippi G, Plebani M. Red blood cell distribution width ( RDW ) and human pathology . One size fits all. Clin Chem Lab Med. 2014;1-3. https://doi.org/ 10.1515/cclm-2014-0585. 
11. Spadaro S, Taccone FS, Fogagnolo A, Franchi F, Scolletta S, Ragazzi R, et al. The effects of blood transfusion on red blood cell distribution width in critically ill patients: a pilot study. Transfusion. 2018;58:1863-9. https://doi. org/10.1111/trf.14759.

12. Fogagnolo A, Spadaro S, Taccone FS, Ragazzi R, Romanello A, Fanni A, et al. The prognostic role of red blood cell distribution width in transfused and non-transfused critically ill patients. Minerva Anestesiol. 2019:1159-67.

13. Gogos CA, Drosou E, Bassaris HP, Skoutelis A. Pro- versus Antiinflammatory Cytokine Profile in Patients with Severe Sepsis: A Marke for Prognosis and Future Therapeutic Options [Internet]. J Infect Dis. 2000:176-80. Available from: https://academic.oup.com/jid/articleabstract/181/1/176/892417.

14. Kobayashi M, Tsuda Y, Yoshida T, Takeuchi D, Utsunomiya T, Takahashi H, et al. Bacterial Sepsis and chemokines. Curr Drug Targets. 2006;7:119-34. https://doi.org/10.2174/138945006775270169.

15. Bazick HS, Chang D, Mahadevappa K, Gibbons FK, Christopher KB. Red cell distribution width and all-cause mortality in critically ill patients. Crit Care Med. 2011;39:1913-21. https://doi.org/10.1097/CCM.0b013e31821b85c6.

16. Musikasinthorn C, Harvey S, McKnight CL, Inouye D, Kuroda J, Nakamura C, et al. Red cell distribution width (RDW) as predictor of hospital mortality in critically ill patients. Crit Care Med. 2014:42:466

17. Perlstein TS, Weuve J, Pfeffer MA, Beckman JA. Red blood cell distribution width and mortality risk in a community-based prospective cohort: NHANES III: RDW and mortality risk. Arch Intern Med. 2009;169:588-94. https://doi. org/10.1001/archinternmed.2009.55.

18. Patel KV, Semba RD, Ferrucci $L$, Newman AB, Fried LP, Wallace RB, et al. Red cell distribution width and mortality in older adults : a meta-analysis. J Gerontol A Biol Sci Med Sci. 2010;65A:258-65. https://doi.org/10.1093/ gerona/glp163.

19. Uyarel H, Isik T, Ayhan E, Ergelen M. Red Cell Distribution Width ( RDW ): A novel risk factor for cardiovascular disease. Int J Cardiol [Internet]. Elsevier Ireland Ltd; 2011;351-352. Available from: https://doi.org/10.1016/j.jicard. 2011.10.126

20. Ani C, Ovbiagele B. Elevated red blood cell distribution width predicts mortality in persons with known stroke. J Neurol Sci. Elsevier B.V.; 2009;277: 103-8. Available from: https://doi.org/10.1016/j.jns.2008.10.024.

21. Sicaja M, Pehar M, Star B, Vuleti V, Bo V. Red blood cell distribution width as a prognostic marker of mortality in patients on chronic dialysis: a single center, prospective longitudinal study. Croat Med J. 2013;54:25-32. https:// doi.org/10.3325/cmj.2013.54.25.

22. Şenol K, Saylam B, Kocaay F, Tez M. Red cell distribution width as a predictor of mortality in acute pancreatitis. Am J Emerg Med. 2013;31:687-9. https://doi.org/10.1016/j.ajem.2012.12.015.

23. Fontana V, Bond O, Spadaro S, Annoni F, Nobile L, Badenes R, et al. Red cell distribution width after subarachnoid hemorrhage. J Neurosurg Anesthesiol. 2018;30:319-27. Lippincott Williams and Wilkins. https://doi.org/10.1097/ ANA.0000000000000459.

24. Hong N, Oh J, Kang S, Kim S, Won H, Chan J, et al. Red blood cell distribution width predicts early mortality in patients with acute dyspnea. Clin Chim Acta. Elsevier B.V.; 2012;413:992-97. Available from: https://doi. org/10.1016/j.cca.2012.02.024

25. Chen C-K, Lin S-C, Wu C-C, Chen L-M, Tzeng I-S, Chen K-F. The utility of red cell distribution width to predict mortality for septic patients visiting the emergency department. Medicine (Baltimore). 2016;95:e3692. https://doi. org/10.1097/MD.0000000000003692.

26. Kim J, Kim K, Hyuk J, Hwan Y, Eui J, Yun T, et al. Red blood cell distribution width as an independent predictor of all-cause mortality in out of hospital cardiac arrest. Resuscitation [Internet]. European Resuscitation Council, American Heart Association, Inc., and International Liaison Committee on Resuscitation. Published by Elsevier Ireland Ltd; 2012;83:1248-52. Available from: https://doi.org/10.1016/j.resuscitation.2012.01.038.

27. Fontana V, Spadaro S, Villois P, Righy Shinotsuka C, Fogagnolo A, Nobile L, et al. Can red blood cell distribution width predict outcome after cardiac arrest? Minerva Anestesiol. NLM (Medline); 2018;84:693-702. https://doi.org/ 10.23736/S0375-9393.17.12102-4.

28. Jo YH, Kim K, Lee JH, Kang C, Kim T, Rn HP, et al. Red cell distribution width is a prognostic factor in severe sepsis and septic shock. Am J Emerg Med [Internet]. Elsevier Inc.; 2013;31:545-8. Available from: https://doi.org/10. 1016/j.ajem.2012.10.017.

29. Kim CH, Park JT, Kim EJ, Han JH, Han JS, Choi JY, et al. An increase in red blood cell distribution width from baseline predicts mortality in patients with severe sepsis or septic shock. Crit Care [Internet]. 2013;17:R282. Available from: http://ccforum.com/content/17/6/R282.

30. Jones AE, Stephen $T$, Kline JA. The sequential organ failure assessment score for predicting outcome in patients with severe sepsis and evidence of hypoperfusion at the time of emergency department presentation. Crit Care Med. 2009;37:1649-54. https://doi.org/10.1097/CCM.0b013e31819def97.

31. Pourhoseingholi MA, Vahedi M, Rahimzadeh M. Sample size calculation in medical studies. Gastroenterol Hepatol from Bed to Bench. 2013;6:14-7. https://doi.org/10.22037/GHFBB.V611.332.

32. Puskarich MA, Sepsis JAE. In: Tintinalli JE, Stapczynski JS, Ma OJ, Yealy DM, Meckler GD, Cline DM, editors. Tintinalli's Emerg Med A Compr study Guid. 8th ed. McGraw-Hill: Mc-Graw-Hill Education; 2016. p. 1021-9.

33. Angus D, Linde-Zwirble W, Lidicker J, Clermont G, Carcillo J, Pinsky M. Epidemiology of severe sepsis in the united States_ analysis of incidence, outcome, and associated costs of care. Crit Care Med. 2001;29:1303-10.

34. Tape TG. The Area Under an ROC Curve [Internet]. Interpreting Diagnostic Test, University of Nebraska Medical Center [cited 2018 Oct 22]. http://gim. unmc.edu/dxtests/ROC3.htm

35. Fontana V, Spadaro S, Bond O, Cavicchi FZ, Annoni F, Donadello K, et al. No relationship between red blood cell distribution width and microcirculatory alterations in septic patients. Clin Hemorheol Microcirc [Internet]. IOS Press; 2017;66:131-141. Available from: http://www.ncbi.nlm.nih.gov/pubmed/2 8128746. https://doi.org/10.3233/CH-160154. [cited 202018 Feb].

\section{Publisher's Note}

Springer Nature remains neutral with regard to jurisdictional claims in published maps and institutional affiliations.
Ready to submit your research? Choose BMC and benefit from:

- fast, convenient online submission

- thorough peer review by experienced researchers in your field

- rapid publication on acceptance

- support for research data, including large and complex data types

- gold Open Access which fosters wider collaboration and increased citations

- maximum visibility for your research: over $100 \mathrm{M}$ website views per year

At BMC, research is always in progress.

Learn more biomedcentral.com/submissions 